\title{
Miranda
}

Revue pluridisciplinaire du monde anglophone /

Multidisciplinary peer-reviewed journal on the English-

speaking world

$12 \mid 2016$

Mapping gender. Old images ; new figures

\section{Reconsidering the Use of Gender Stereotypes in Medieval Romance: figures of vulnerability and of power}

\author{
Lesley Lawton
}

\section{OpenEdition}

Journals

Electronic version

URL: http://journals.openedition.org/miranda/8646

DOI: $10.4000 /$ miranda.8646

ISSN: 2108-6559

\section{Publisher}

Université Toulouse - Jean Jaurès

\section{Electronic reference}

Lesley Lawton, "Reconsidering the Use of Gender Stereotypes in Medieval Romance: figures of vulnerability and of power", Miranda [Online], 12 | 2016, Online since 02 March 2016, connection on 16 February 2021. URL: http://journals.openedition.org/miranda/8646 ; DOI: https://doi.org/10.4000/ miranda.8646

This text was automatically generated on 16 February 2021.

\section{cc)}

Miranda is licensed under a Creative Commons Attribution-NonCommercial-NoDerivatives 4.0

International License. 


\title{
Reconsidering the Use of Gender Stereotypes in Medieval Romance: figures of vulnerability and of power
}

\author{
Lesley Lawton
}

Act One of Caryl Churchill's 1982 play, Top Girls, shows Marlene hosting a dinner party in a London restaurant to celebrate her promotion to managing director of "Top Girls" employment agency. Her five guests are women either from the past or from literature and legend. In order of arrival they are Isabella Bird (1831-1904), writer and explorer; Lady Nijo (b. 1258), one of the Japanese Emperor's courtesans and, after his death, a Buddhist nun; Dull Gret, the subject of Bruegel's painting, Dulle Griet (1562), ${ }^{1}$ a depiction of the proverbial Flemish saying that an aggressive woman could "plunder in front of hell and return unscathed"; Pope Joan, who, as late-medieval legend had it, disguised as a man, was Pope from 854-856 and was unmasked when she gave birth during a procession; and finally, arriving too late to eat anything other than dessert, Patient Griselda. Marlene introduces her as being "in Boccaccio and Petrarch and Chaucer because of her extraordinary marriage" (Churchill 22). ${ }^{2}$ Her story emerges in the course of the meal: Walter, the marquis, chose her, a peasant girl used to poverty and harsh living, to be his wife on the condition of absolute obedience. This promise was put to the test after the birth of her first child, a daughter, whom Walter ordered to be taken away and killed on the grounds that his subjects disliked Griselda and her child because they were of peasant stock. Griselda made no protest, for the child was "Walter's to do what he liked with" (25). A similar thing happened a few years later when Griselda gave birth to a son. The penultimate test was that Walter sent her back to her father having stripped her of all her fine clothes, except a slip for modesty, because he was about to marry someone who could give him an heir who would be acceptable to his people. Then, as a final demand for service, he commanded her to come back and help prepare the wedding as she knew how to arrange things the way he liked them. Just before the marriage could take place, Walter revealed that the new "bride" and the page who 
accompanied her, were in fact her children whom he had brought up secretly. All this had been a series of trials, designed to test her love for him. The other characters react in ways appropriate to their own subject positions. Only Nijo, used to the arbitary exercise of power over her as a courtesan, shows any empathy for Griselda's story. Isabella, the cultural anthropologist, is curious but non-judgemental, paying tribute to Griselda's "sweet nature" (28). Marlene trenchantly gives her modern reaction to the power relationships in this marriage: "Walter was bonkers" (25). ${ }^{3}$ Griselda, however, is confident of the rightness of her obedience, her account of Walter's behaviour being characterised by a serene acceptance. She explains that her decisions were "always easy because I always knew I would do as he said" (26). She even expresses pity for Walter driven to test her in this way: "He suffered so much all those years" (28).

2 All five of Marlene's guests in Churchill's play were carefully chosen to reveal facets of a woman's social role and problems of submission and domination in their relationships with men. The play as a whole asks some hard questions about what it means to be a modern woman and the price she must pay to achieve success. All the female employees of the "Top Girls" employment agency have sacrificed their personal lives for their careers. The issue of a woman's role in public life was particularly pertinent in 1982, during Margaret Thatcher's first premiership. By including Griselda among her cast, Churchill demonstrates the potency and persistence of the archetype of the eternally accepting, patient woman, who saves her man and her family through her faithful obedience. The self-abnegation which forms part of a dialogue about the female role in Churchill's play shows the endurance of Griselda as a feminine type; she is presented here as one extreme form of unsatisfactory femininity to be set against the others. Griselda is implicitly compared and contrasted with more "masculine" women, such as Marlene herself, who also abandoned her daughter-in pursuit of her career, rather than with the aim of placating a husband. Margaret Thatcher, a powerful extratextual presence evoked in the play, is also depicted as that man-like woman, the virago. As Marlene's sister, Joyce, asks, "What good's the first woman [prime minister] if it's her? I suppose you'd have liked Hitler if he was a woman" (93). ${ }^{4}$

Churchill's use of the Griselda stereotype demonstrates that contemporary society is still haunted by models of femininity shaped in the Middle Ages. Indeed, in the modern consciousness, Griselda has been conflated with another archetype of female vulnerability, that of the damsel in distress. ${ }^{5}$ The latter is a figure which of course predates the Middle Ages, ${ }^{6}$ but is an essential ingredient of medieval romance since all good knights have their ladies whom they must serve and, if necessary, defend and rescue. As a married woman Griselda is not, strictly speaking, a damsel, nor, given that her suffering is gladly accepted, is she in distress, yet the fact that she was an important, if inaccurate, point of reference for the author of the Wikipedia entry on the subject, demonstrates the way the Griselda type gathers together other associations. Churchill shows her indebtedness to the Middle Ages in other ways. In her pairing of Griselda with Margaret Thatcher, Churchill draws on a technique used by writers of medieval romance: the doubling and juxtaposition of the characters, a technique to be seen in other traditional narratives such as fairy tale and folk tale. ${ }^{7}$ In the romances to be discussed here the "splits" or "repeats" are not just those of the protagonist, but form a noteworthy structural pattern. As in Churchill's play, in medieval romance the figures of women are not limited to passive, suffering victims; "good" women are frequently paired with potent, threatening termagants. 
Indeed, the stereotypes to be found in medieval romance still speak to a modern audience since romances share with other traditional narratives a tendency to use narrative patterns which, by their recurrence, indicate that they connect with the deep structures of the human imagination and of cultural practice. As Propp has demonstrated to be the case with folk tale or fairy tale, the characters in medieval romances tend to perform narrative functions rather than having an individualised interiority of the sort we may associate with a certain kind of modern fiction. Stereotypes are thus an inevitable consequence of this type of writing for they provide an instantly recognisable shorthand for certain categories of behaviour or narrative possibility. Like fairy tales and folk tales, many romances derive their psychic power from their presentation of family relationships, dealing with the individual's progression towards an adult identity. ${ }^{8}$ If a woman is to be the heroine, in many medieval romances she is often doubled with a negative example of femininity. The roles assigned to women are usually limited to those of mothers, wives, mistresses, daughters and occasionally healers and helpers like the abbess in Lay le Freine who acts as substitute mother for the eponymous heroine. Where women overtly display power, they are often wicked.

Yet stereotypes may be deployed in literary works in ways which may disrupt or even subvert the basic type. In the romances I shall consider, the use made by medieval authors of the traditional store of narrative patterns and the motifs on which they draw for their own purposes needs to be examined. I will argue that in these literary works, even in the least artistically sophisticated, the contours of stereotypes may become unstable and their underlying clarity become blurred. This paper limits itself to three representative romances, Sir Degaré, Lay le Freine and Sir Launfal, before returning to Griselda in her complex incarnation in the work of Chaucer. Though Griselda's story begins where many romance narratives end-with a marriage-it shares with them an attempt to explore in symbolic form certain issues of male and female identity.

\section{Psychic and social identities}

6 The Middle English Breton Lays form a useful corpus for understanding the way these foundational stereotypes operate in medieval romance in general. ${ }^{9}$ As they are a brief example of the form they present the issues in a concentrated way. Figures of vulnerability, the damsel in distress and the persecuted wife, together with figures of power, the nurturing mother and their dark doubles-wicked queens and devouring mothers-people the diegesis. Though women are important subsidiary figures, relatively few romances take a woman's life as their main subject. Generally it is the male experience which is the focus and it is the vulnerability of the woman-her role as "damsel in distress"-that gives him the opportunity to demonstrate his worthiness. The knight affirms his masculinity by winning a damsel as his prize; maidens may therefore be central to the enterprise of the quest, but marginal to the narrative. Women are primarily defined by their sexuality; that is, by their capacity to allure and inspire the male, and to fulfill their reproductive capacities and obligations. The female narrative trajectory reflects the different gender expectations of the original audiences. Rather than knightly proving, the female protagonist experiences a change of status, sometimes from security to abandonment and exile, and certainly from 
daughter to wife to mother. The end result is the same for both the male and female protagonist: marriage and family. ${ }^{10}$

$7 \quad$ Sir Degaré and Lay le Freine form a useful contrasting pair to explore the ways in which the romance develops with a feminine rather than a masculine protagonist. Both lays are essentially coming-of-age stories in which personal development is seen as a movement through the subject positions appropriate to gender rather than a development of subjectivity. Sir Degaré recycles material from folktale in a relatively undigested way, but even here a certain blurring of gender stereotypes can be seen. Starting from the same motifs, the narrative development in Lay le Freine is very different because of the protagonist's gender. This female story, like that of Griselda, also operates on an exemplary level, being concerned in this case with what constitutes a decorous use of speech for a woman, using negative female stereotypes to reinforce its message. Sir Launfal is the most interesting of the lays in its interrrogation of gender stereotypes and it is here that powerful women make their entry. Launfal is subjected to a shameful stripping away of his knightly identity. His antagonist, Guenevere, is a compilation of stereotypes of evil women from the Bible to fairy tale, adding the threatening aspects of a devouring sexual appetite to the mixture. ${ }^{11} \mathrm{Her}$ arrogation of sexual and political power requires an equally powerful female helper for the hero in the form of a fairy mistress. Like the eponymous heroine of Lay le Freine, Griselda proves her heroism by suffering rather than acting. It is her self-abnegation which enables her to triumph in the end, regaining the husband, children and social recognition that is the destiny of women protagonists in romance. Her story combines the romance motifs of loss and restoration with some of the features of parable. However, Chaucer, unlike Churchill, intensifies the contradictory significance of this figure in The Clerk's Tale, putting such pressure on the story as to put the type into question.

8 The coming-of-age story for both men and women in medieval romance often involves a potential violation of the incest taboo. T. A. Shippey describes the deep structures involved in the protagonists' search for identity that are frequently to be found in fairy tale:

In the male version, the job of the protagonist [...] is to 'kill his father, dodge his mother, and win his girl' (and along with the girl, freedom, maturity and escape from the home). The female version meanwhile reverses the sexes, so that it is the father's love which has to be avoided, and also for cultural reasons allows the heroine only a less active role: she has to show herself to Prince Charming and then wait for his advances rather than running boldly after him. (69)

Indeed, one of the procedures of romance appears to be to raise and quell all kinds of questions about the family, about succession and about transmission between the generations. However, the construction of a social identity is as important in romance as the development of the individual adult psyche. Anthropological considerations are thus as important as those of psychoanalysis. Jean-Jacques Vincensini argues for the fruitfulness of an anthropological approach to medieval texts, noting that they materialise cultural issues through narrative structuring (192). ${ }^{12}$ Clearly, incest prevents exogamous alliance among families. It violates the principle of exchange on which patriarchal society is built (Kisor 144). ${ }^{13}$ Just as incest prevents the free circulation of women in society, so the motif often creates a narrative blockage in those romances which have a female protagonist and it is the attempt to evade the father that motivates the events that follow. ${ }^{14}$ The incestuous father is one of the ways in 
which women are rendered vulnerable by their sexuality. Yet since the main aim of this kind of narrative is to remove the protagonist of either sex from the family structure so he or she may develop or display those qualities which can lead to maturationphysical prowess in the case of the male, more traditional "feminine" qualities in the case of the female-the catalyst may also be the mother or a mother figure.

Both Sir Degaré and Lay le Freine share the motifs and preoccupations of tales of identity formation and are both concerned with the stabilisation of the social group. The significance of tokens which enables the protagonists to be recognized and acknowledged by their kinship groups also demonstrates the importance of social integration as part of the discovery of identity. Sir Degaré has received attention because of its overt recycling of Oedipal motifs (Aarne-Thompson $\mathrm{N}^{\circ}$ 931). ${ }^{15}$ As James Simpson has noted, "were it not for the date of the text, one would have sworn that this was written by Freud" (128); it is the story of Oedipus with a happy ending which raises, and then nullifies and excludes, some of the darker passages of the family romance. But this concentration on Oedipal material fails to note that the female experience, as described by Shippey, makes its appearance in a modified form, which relates it to other romance and folk tale motifs of female maturation. Sir Degaré in fact has a double structure, the first 180 of the poem's 1103 lines being devoted to Degaré's mother and the circumstances of his conception before switching attention to the male pattern of the quest of the hero for identity and social recognition. Thus female experience precedes and prepares for that of the hero. The prerequisite for the hero's quest is the mother's own adventure that led to his conception.

\section{Masculine and feminine identity formation: damsels in distress and wicked mothers}

11 Degaré's unnamed mother is a Breton princess, the only child and heir of the king whose wife died in giving birth to her. The unstated implication is that her purpose in life will be to bestow herself and her kingdom on her lucky suitor. But to establish that he is a worthy successor to the king, he must pass a test: to defeat the father in combat and thus to prove himself a better man than the present incumbent. A tournament is arranged annually to give any aspiring youth the chance to try his luck. Unfortunately, the father proves invincible. His refusal to marry his daughter to anyone who does not fulfill his conditions thus runs the risk of condemning her to perpetual celibacy. It can be seen that this motif of the impossible condition links this part of the narrative in an attenuated form with those tales in which the father's motive in rendering his daughter inaccessible to other men is the desire to marry her himself. In narratives where the incest motif is overt, the persecuted heroine is forced to leave home and is reunited with her family only after many ordeals (Archibald 56). ${ }^{16}$ The princess in this poem, however, is essentially confined to the palace. Her narrative function as wife has been blocked by her father's exacting conditions. This crisis of succession needs something violent and extraordinary to remove it and the necessary disruptive element comes on the anniversary of the death of the queen when the king and his daughter ride through the forest to the abbey where his wife is buried. She becomes detached from her father's retinue. Though, as we will see, the forest is a place of self-realisation for a knight, it is a place of danger for the damsel. Forests are especially associated with fairies, and it is a fairy knight who rapes her, giving her a broken-tipped sword which 
he charges her to give to the son who, he is certain, will be born. Rape, substituted for the threat of incest, is a means to stave off unproductive endogamy: it is the mechanism which moves the narrative forward for the knight's prediction proves to be correct. The princess is terrified at what people will say and in particular that they will suspect her own father of being the father of her unborn child, in the absence of any other candidate. While the theme of father-daughter incest is attenuated, it is still present as a possibility and comes into prominence at this point.

The child is born in secret, therefore, and abandoned at a nearby hermitage in a cradle containing treasure, gloves and a letter instructing that the foundling be given the gloves when he is ten years old:

"And biddeth him, wharevere he go,

That he ne lovie no womman in londe

But this gloves willen on hire honde;

For siker on honde nelle thai nere

But on his moder that him bere" (11. 214-8)

[And bid him that, wherever he goes, that he not love any woman in the land unless these gloves fit on her hand; for certainly they will not fit on any hand save that of his mother that bore him]

The wording is somewhat ambiguous. Though the gloves can function as a means of recognising the mother and thus avoiding an incestuous alliance, the invitation only to love the woman on whose hands the gloves fit, rather than stipulating that he should love any woman except the woman on whose hands the gloves fit, evokes the prospect of mother-son incest. This invitation to transgression is an indication that finding a wife, an essential stage in Degaré's development, is potentially equivalent to finding his mother. This imprecision of generational roles recalls the earlier possibility of the father-daughter incest which the fairy knight had both exorcised (in that the son was exogamously conceived) and aroused (in that the princess feared that her father would be suspected of having violated her). Furthermore, the sexual suggestiveness of the objects that the characters exchange is not accidental. The gloves are an obvious female emblem, just as the sword is a masculine one. Thus, Greek tragedy is crossed with fairy tale here; Jocasta is attenuated by Cinderella.

The narrative now focuses on its male protagonist, describing Degaré's upbringing and early adventures before arriving at a mother-son reunion which also brings about a return to the incest theme. At the age of twenty Degaré is given the gloves and the letter and sets forth from the hermitage. The forest becomes the stage for his selfdiscovery and knightly testing. His quest exists on three levels. As an individual, he needs to prove his knightly value, achieving social status and the worthiness to found his own family. In the course of his journeys, Degaré's progress towards a satisfactory chivalric identity is indicated by his acquisition of knightly accoutrements. He leaves the hermitage on foot armed only with an oak sapling, having refused the hermit's offer to provide him with the horse and armour that the money left in his cradle might have bought. His first adventure in the forest is to rescue an earl from a dragon, thus demonstrating his natural strength. As a reward, among other things, the grateful earl dubs him a knight, giving him the horse, armour and squire which go with his status. With each subsequent encounter, Degaré gets better equipment so in his final battle, that against his father, he is described as wearing a splendid, richly bejewelled helmet and carrying a shield that is gorgeously embellished with golden heraldic emblazonings. The second level of his quest, the social one, is to recompose his kinship 
group by discovering his family and his lineage. Indeed, he does not leave the hermitage in quest of adventures as such, but in quest of his parents. As he says, the gloves that will only fit his mother will (like Cinderella's slipper) allow him to identify her. On the final level, the romance charts Degaré's progress towards psychic and sexual autonomy through the avoidance and transformation of the two Oedipal obstacles described by Shippey-attraction towards the mother and rivalry with the father. Romance and fairy tale depict the same basic conflicts as tragedy but manage to convert the outcome into a happy one.

Degaré's quest becomes imbued with the theme of incest, as has already been intimated. He delivers his mother from the possessive love of her father by beating his grandfather in the tournament which is still being proclaimed twenty years after his conception and it is he who finally wins his mother as his prize. Fortunately, he remembers to try the gloves on her before the marriage is consummated, thus averting incest and turning the scene into one of family reunion instead. It seems necessary in this romance to evoke the possibility of transgression and for it to be avoided for restoration to take place. Degaré's mother is able to transmit to him his father's sword, the breadth, length and weight of which is cause for admiration. As Degaré says: “"Whoso it aught, he was a man!" (1. 712) [Whoever owned it, he was a man!]. His purpose is now to seek his father. The reunion with his father appears to be an essential element in the transition from endogamy to exogamy since between nearly marrying his mother and finding his father, Degaré encounters an eligible maiden, but postpones the marriage in favour of his search. Meeting his father by chance in the forest, Degaré is challenged to a duel but the pointless sword that he, the stronger knight, is wielding acts as a token by which his father can recognise him and to which he can add his own contribution for he keeps the missing point in his purse. Thus parricide is avoided and the defective phallic object bestowed on Degaré by his mother is completed by his father as an emblem of the achieved sexual maturation of the hero. The father plays a part in phallic construction, though the hero proves his virility by superseding both his father and his grandfather. Proper relations are now established as Degaré takes his father back to his mother's castle where they finally get married. The parents are present at Degaré's own marriage which ends the romance. Thus the psychological dimension of the poem is intertwined with wider social concerns. The motif of exile and return is a fundamental one in romances in general. As James Simpson points out:

The wholeness of the individual hero is impossible without the correlative wholeness of the kinship group to which he belongs; his own maturation is identical with the job of restoring the proper cohesion of the previous two generations. (130)

The symbolic logic of family recomposition under the guiding hand of the enterprising child shows that, here, it is the child who creates the parental couple and not the reverse.

But even in a romance such as this in which an analysis of the story is so receptive to templates drawn from Freudian and anthropological theory, female roles are unstable. The identity of the maiden who becomes Degaré's wife shifts interestingly and mysteriously in the middle of the narrative. In the region of the forest where the fairy knight had appeared to his mother, Degaré sees a castle "amidde a river" (1. 740). Invitingly, the drawbridge is down and the gate is open so he enters but there is no one there although a fire is lit on the hearth. Four maidens, dressed as huntresses, carrying bows and arrows and laden with venison enter the hall but fail to respond to Degarés 
greeting and go into a private room. A dwarf then enters and proceeds to set out the hall for supper, ignoring Degaré all the while. At this point a beautiful maiden comes out of the bedchamber with her attendants. All are equally silent during the feast in which Degaré participates. Afterwards the women retire to the bedchamber. Degaré, who is completely smitten by this time, joins the lady on her bed, but falls asleep to the sound of the harp played by one of the maidens. This concentration of Celtic motifsthe castle on the island in the middle of the river, which is apparently deserted but in which burns a welcoming fire, the mysterious behaviour of the silent maidens and their equally mysterious entrances, the fact that some of them are huntresses, the soporific powers of the harp-playing-all connote the magic otherworld and indicate that Degaré may be in thrall to fairy enchantment. But this proves not to be the case. The maiden tucks him up warmly and when she wakes him in the morning teases him about his failure in the arts of the bedroom, prompting Degaré to apologize profusely. Up to now the maiden has had the power in the scene, the power to speak or be silent, the power to ignore or to acknowledge, and the power to judge performance or lack of it. She is, then, potentially, in the position, if not of fairy mistress, then of the exacting mistress of courtly love whose will her knight must obey. However, her function shifts. She turns out merely to be a damsel in distress who needs a champion to rid her of an unwanted suitor who is besieging her and has killed all the men in the castle. She merely provides Degaré with another opportunity of giving a display of chivalric prowess. The fact that the castle was left wide open on the previous day would seem incompatible with a state of siege, but romances do not operate by strict realistic logic or consistency. When the interest of the narrative requires the lady of the castle to be mysteriously powerful she is, and when she needs to be subordinated to the onward drive of Degaré's achievements, she is unceremoniously pushed to the margin. Perhaps the very indeterminacy and shifting quality of her role points to some unease about the nature of female power, since she is rapidly reconsigned to the stereotyped role of maiden and prospective bride in need of her knight in shining armour.

The narrative unit of the abandoned foundling which Sir Degaré shares with the Oedipus story has its female equivalent in Lay le Freine, a relatively close translation of Marie de France's Lai le Fresne written in Anglo-Norman French in the late twelfth century (Laskaya and Salisbury 61). Whereas the possible female roles in Sir Degaré were maiden, mother and wife, with a quickly suppressed hint of fairy mistress, the female roles in Lay le Freine include that of the wicked mother. The abandoned child theme in both romances attracts to itself the subsidiary motifs of the problematic birth and the tokens which eventually allow the child to be recognized. In both poems, the point of departure which drives the narrative, the expulsion of the child from the home with the consequent need for the discovery and assertion of the protagonist's true identity, is caused by the mother rather than the incestuous father. However, Lay le Freine's narrative of female identity formation becomes an exemplum, encapsulating a message about female conduct, rather than a story of adventures. In the working out of the story we are to see encoded the ideals of correct behaviour in a culture. It is "a moral tale which condemns envy and slander while rewarding silence, patience and generosity" (Laskaya and Salisbury 62). The female protagonist is thus placed in a more complex discourse about feminine qualities as well as being part of a woman's comingof-age narrative. figure being rendered more wicked in contrast to her innocent child. It begins with the 
announcement to a Breton knight that his bosom companion's wife has just been safely delivered of twin sons. Though the knight expresses his gladness, his wife, presented as a recognisable medieval stereotype of the jealous, gossiping woman, scornfully delivers her opinion that the birth of twins signifies that the woman has had sexual relations with two different men. ${ }^{17}$ In medieval literature, women's speech is often problematic. ${ }^{18}$ Women are associated with cultural fears about their perverted speech. Le Freine's mother, is, as the narrator points out, guilty of a number of the female "sins of the tongue". She is:

Hokerfulliche missegging,

Squeymous and eke scorning. (11. 61-62)

[Maliciously slandering, disdainful and also scorning]

'Misseggen' can be glossed as "to slander", but it literally means to mis-say, in other words to deform the proper purposes of speech, as the negative prefix to the verb indicates. Indeed, this is what the wife admits to having done at the end-"Hou of her neighbour sche had missayn" (1. 391)-in a scene, typical of romance, in which all is resolved through open avowal and acknowledgement. The culpability of Le Freine's mother is emphasised by the attribution of the qualifier "milde" (1. 33) to the other knight's wife, an appellation which intensifies the contrast between the two women. With the inevitable logic of romance, the slandering woman is herself delivered of twins-girls this time-and draws the moral lesson, that each woman should be forbidden to speak harm of another (11. 91-92). The first couple has no further part to play in the narrative, suggesting that their function is just to double up with the main protagonists, as happens in fairy tales. The mother of the twin girls realises that she has only a limited number of alternatives-either to admit that she has had two lovers, which is untrue, or to admit that she lied about her neighbour, or to kill one of the children. Cold-bloodedly she inclines towards the latter option, but fortunately one of her servants suggests the possibility of abandoning one of the children. Like Degaré, the baby is accompanied by tokens which declare her to be of "riche kende" (l. 144): she is wrapped in a richly embroidered cloth and a gold ring is attached to her arm with a silk thread. Like Degaré, the baby is given a more-or-less arbitrary name which is no indicator of identity. As she is deposited inside a hollow ash tree outside a nunnery, the abbess who adopts her calls her "Freine." Thus Lay le Freine begins with a cruel, rejecting mother.

21 The female narrative takes place almost exclusively in interiors. Brought up in the nunnery, Le Freine attracts the attention of a young nobleman, Guroun, who persuades her to become his mistress and to leave with him. Le Freine thus merely exchanges the inside of the nunnery for the inside of Guroun's castle. Her destiny is exclusively based on the fact of her capacity to attract a man, but her obscure birth means that she is downgraded to mistress rather than being made a wife. This is the reason why Guroun's knights beg him to put her aside and take a wife who can bear him legitimate and appropriate offspring. They propose a knight's daughter as a suitable candidate-who turns out to be Le Freine's twin sister. The threat of incest, therefore, comes not vertically from the parental generation but horizontally from the potential marriage of brother and sister-in-law, a degree of consanguinity that was forbidden in the Middle Ages. The importance of the kinship group is again primordial. "Much written discussion surrounding the issue of abandoned children stresses the possibility that incest can result because bloodlines are not known" (Laskaya and Salisbury 86). The marriage is planned and Le Freine takes part in the preparations to the point where, 
considering that the marriage bed is insufficiently decorated, she spreads her rich cloth on top of it. This is the token by which the mother recognises her daughter, acknowledges her and thus bestows a social identity upon her by integrating her into her family group. The marrriage between Guroun and Le Freine can then take place. The sister, disposed of rapidly by being married off to another suitable knight, is, like the twin boys at the beginning, supernumerary, a function, on one level, of the poem's interest in doubles and parallels.

Le Freine is the complete opposite of her mother. She is described as being "hende [pleasant, courteous, gracious] of mouth" (1.265). Where her mother is garrulous, she is silent, not only in the sense that she does not speak, but also because she is shown actively avoiding negative speech acts: though her heart is breaking when she participates in the organisation of Guroun's marriage to her sister: "No word of pride ne grame [anger] she spoke" (1. 354). Unlike her mother, whose words are transcribed at length in direct discourse, Le Freine is never shown speaking directly until her mother addresses her in the wedding chamber (1. 379). Though refraining from speech may be a positive thing, failure to speak, leading to secrecy, may also be a lie of omission, of concealing something which needs to be revealed. The mother finally shows herself capable of reparative speech by disclosing her story and acknowledging Le Freine as her daughter. "Le Freine's acquisition of a voice in the story and her reclamation of identity, heritage, and family (especially her mother) clearly coincide" (Laskaya and Salisbury 65). Until the recognition scene, Le Freine only "speaks" through an object. It is her unsolicited act of consideration in wishing to offer her one possession for her partner and her rival's pleasure that enables her to transform her embroidered cloth into the token of recognition that allows her to triumph in the end. The subliminal message to women seems to be clear: they achieve their desires by serving others and holding their tongues. Power comes through subservience and selfrepression.

The plot device of being repudiated by the husband and helping to prepare for the new bride connects Le Freine with the Griselda type. However, unlike Le Freine, Griselda is rewarded purely as a result of her actions: it is her self-sacrifice and self-denial which is the cause of her being finally accepted by her husband; there is no token which forces recognition of a more socially acceptable identity. Griselda displays her faithfulness to her promise of obedience under the most harrowing of circumstances; Le Freine displays an object. It may be for this reason that the method by which her real identity becomes known can be seen as ambiguous. Just as a cover both conceals and reveals, so Le Freine's act of self-abnegation in offering her cloth as a cover for the bed in which she will be displaced can also be seen as a means of self-affirmation, a metonymic spreading of herself on the nuptial couch (Vial 124-125). Though her origins are unknown, she comes from the very social class which would make her an acceptable spouse for Guroun. For those who know how to read the signs, this is the statement that her gesture makes. Fortunately for Le Freine, her mother is there to read it. Once again the lays address anxieties about the definition of social status and its potential loss.

24 It is through the reunion with the mother that Le Freine is able to take her place at the side of her husband. As in Sir Degaré, the family needs to be regulated and secrets need to be revealed before the younger generation can, in its turn, achieve stability. These two romances which display many of the typical patterns of the romance mode-loss 
and restoration, separation and reunion, exile and return, testing and reward-show to what extent identity is conceived of as a public recognition of what one is considered to be.

\section{Interrogations of identity: powerful women and female heroism}

The late fourteenth-century Sir Launfal by Thomas Chestre, based on Marie de France's twelfth-century Lanval, deals with loss and restoration like Sir Degaré and Lay le Freine, but this time identity needs to be reconstructed rather than discovered. Morevover, the gender construction of the protagonist is placed under pressure as he is the one who becomes vulnerable thanks partly to the machinations of a powerful woman. Indeed it is Launfal who occupies the damsel-in-distress subject position in several of the poem's narrative sequences. Thus Sir Launfal is a romance which at once reveals and questions the components of chivalric identity.

As in Sir Degaré and Lay le Freine, the protagonist is expelled from the group by a rejecting woman, who is the plot device that initiates the narrative. Launfal begins the lay almost where Degaré finishes, as an important part of a prestigious knightly group. Steward to King Arthur because of "hys largesse and hys bounté" (1. 31) [his generosity and his munificence], his identity seems to be stable. It is to a great extent based on his primary chivalric quality of generosity, expressed as a form of public display. But public recognition, identity as validation in the eyes of others, is also an important component of the chivalric self. In what must have been the worst piece of advice he ever gave, Merlin counsels Arthur to marry Guenevere and the marriage takes place at the beginning of the poem.

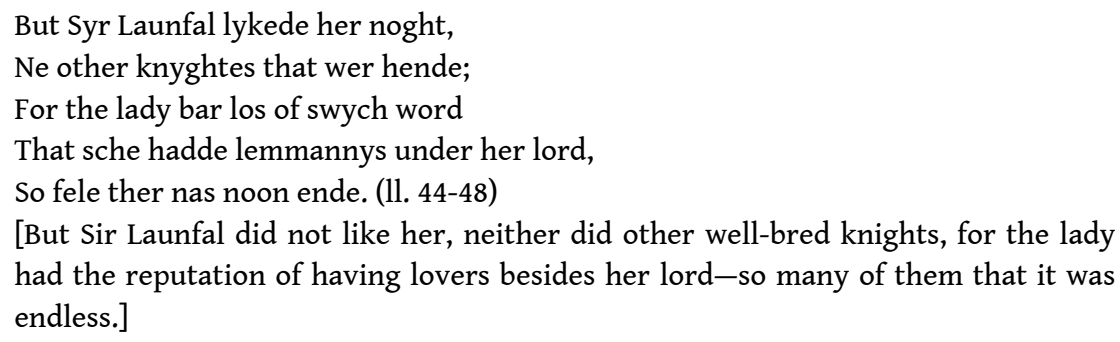

She is thus a stereotype of the sexually insatiable, devouring woman as the hyperbole of her countless number of lovers makes clear. However, the dislike is mutual and while Guenevere distributes lavish gifts at the wedding feast, she gives Launfal nothing. It is her public snubbing of him in the gift economy of the court that prompts his leaving for the town. What happens next is a gradual stripping away of knightly identity as Launfal is exposed to the realities of being out of royal favour and of having financial problems. Part of the role of being a knight is to spend lavishly, to wear the right clothing and to have two horses: one for himself and one for his squire. All this involves considerable expense. So "savagelych" does he spend his money, we are told, that he is in debt after the first year. Launfal's poverty is so despised by the townsfolk that he is not invited to a local feast and he feels too humiliated by his bedraggled clothing to show his face in church. The accumulation of public shame continues. To distract himself, he asks his landlord's daughter if he may borrow a saddle and bridle so he may ride out into the countryside for a change of scene. The fact that he has had to sell part of his chivalric equipment would have indicated to the medieval audience the depth of 
his financial and social degradation. His downward movement continues literally as his horse slips in the mud under the scornful gaze of the onlookers.

Fleeing the scene of his disgrace, Launfal enters the forest which, as we saw in Sir Degaré, can be a permeable place, a threshold between the human and the fairy worlds. Two maidens appear, bidding him to visit their lady, Dame Tryamour, the daughter of the "Kyng of Fayrye." Launfal discovers her lying on her bed in a costly tent, which the narrator makes clear is of a sumptuousness out of the reach of common mortals, partly naked because of the heat:

For hete her clothes down sche dede

Almest to her gerdylstede

Than lay sche uncovert.

Sche was as whyt as lyly yn May,

Or snow that sneweth yn wynterys day -

He seygh never non so pert. ( 11. 289-294)

[Because of the heat she lowered her clothes almost to her waist so that she was

uncovered. She was as white as a lily in May or the snow that snows on a winter's

day. He never saw anyone so beautiful.]

For the male protagonist, the fairy visitor is far more invitingly seductive than the threatening rapist who presented himself to Degaré's mother. The impoverished knight is able to appreciate both the lady's beauty and her luxurious possessions. This halfnaked exhibition is a familiar male erotic fantasy but the display of the female body to the admiring gaze as a statement of power also speaks to female fantasy. A.C. Spearing considers that Tryamour here adopts:

the role as a wealthy, self-pleasing and successful seductress. To be looked at is in one sense to submit to a dominant male gaze, but, within the given framework of sexual politics, to attract the gaze is a source of female power. (100).

Tryamour declares her love and promises him that if he will forsake all other, she will give him a magic purse in which he will find a coin every time he puts his hand into it, a steed and a squire, and protection against injury in battle. She thus offers the fantasy of carnal fulfilment, wealth without effort and chivalric success. The sexual suggestiveness of the purse is clear and recalls the use of symbolism in Sir Degaré. However, unlike the purse in which Degaré's father keeps his broken sword point, perhaps representing a harmonious union of male and female elements, this purse is more specifically associated with the female power to bestow or withhold favours, both sexual and financial in this case. After a night of love, Tryamour sends Launfal back to town, the scene of his disgrace, promising to come to him any time he wishes when he is in a private place where no one can see her. She does, however, place upon him one condition: if he speaks about her to anyone, their relationship will be over.

31 Tryamour is a powerful woman on three counts. Firstly, as a fairy being, she is not subject to mortal codes of sexual restraint and morality. Her spontaneous offering of herself to Launfal does not elicit any narratorial disapprobation. This brings into focus the constraints to which mortal women are subject in this domain, the lascivious Guenevere offering a contrasting and negative image of female sexuality. Secondly, Tryamour is instrumental in re-establishing the social status Launfal has lost-an unusual role for a woman-by performing the narrative functions both of helper and of lover. Finally, as well as being a fairy, she is also a mistress, a role that, according to the amour courtois pattern, invests women with a certain degree of power since it is modelled on the feudal relationship between a knight and his liege lord. However, in 
the case of Launfal, the fairy mistress is more in control than is usual with mortal women and Launfal is unusually dependent on her for everything. Indeed, she is even instrumental in reconstructing his chivalric persona.

With his fairy gifts, Launfal proceeds to live with the largesse that was expected of those with a certain status. Sir Launfal is a poem that is very open about the material foundations upon which a knight's ability to function adequately is based. As soon as Tryamour restores his solvability, his public reputation is restored and this results in the staging in his honour of a tournament. Up to this point his martial prowess has not been evoked by the text; as if he were an unproved knight like Degaré, his exploits are now recounted in detail. He wins the prize at the tournament and is thus finally textually established as a fighting champion, a role which is both confirmed and undermined by his next confrontation. A Lombard giant challenges him to a duel in the course of which, much to Launfal's chagrin, his helmet is knocked off. Fortunately, his squire, Gyfre, has the gift of invisibility and quickly replaces it for him. Though Launfal finally succeeds in killing the giant, this success has partly been dependent on the magic underwriting of his prowess rather than, as is the case with Degaré, on his own strength. ${ }^{19}$ These two battles are sufficient for him to be restored to his place at court: news of his exploits reaches Arthur who as a consequence invites him for a feast and gives him back his role as steward. The pattern of return and reintegration is complete and a new series of complications begins.

After the feast is finished, Launfal becomes the subject of the Queen's desiring gaze and she openly tries to seduce him. Her attraction is sudden and unmotivated, more to do with the structural needs of the narrative in its wish to double up the two aspects of passionate women-the positive and the negative. The contrast between the libidinous queen and Tryamour is emphasised at all points. Both are "wooing women" in frankly making their declaration of love. They have the more aggressive sexuality; Launfal's only power is to accept or reject their advances, one welcome, the other unwelcome. This is a subject position more commonly associated with women. He rebuffs the queen, his declared reason being that to make love with her would be an act of treason. The outraged Guenevere accuses Launfal of not liking women very much and Launfal, stung by this insinuation of homosexuality, claims that he is in love with a fairy whose ugliest maiden is more worthy to be a queen than she is. Guenevere, like Potiphar's wife, accuses Launfal of trying to seduce her and when she refused, insulting her with his claim about the discrepancy between her beauty and that of an attendant. Launfal has disobeyed the fairy's interdiction and must suffer the consequences. She will no longer come to him and all the trappings of knighthood underpinned by fairy magic vanish. Furthermore, Arthur institutes legal proceedings against him for treason and lèse majesté. The accusation of Launfal's propositioning the queen is quickly set aside by the court; the real problem is the claim about the relative beauty of the queen and Tryamour's maidens. The rest of the romance turns round the question posed by the fairy-tale step-mother of "who is the fairest of them all?" The queen scoffs that if anyone more beautiful than she can be found, they can put her eyes out.

Launfal is ordered to produce his mistress but is, of course, unable to do so and Arthur commands his barons to execute judgement. While they hesitate, they see a procession of ten maidens riding towards them, of whom the loathliest is, without doubt, more beautiful than the queen. Everyone expects Launfal to claim one of them as his mistress, but he has never seen any of them before. Another ten maidens arrive and the 
pattern is repeated. As a climax a lone damsel comes riding up. It is Tryamour, who drops her rich mantle to the floor to display her body to everyone's gaze. It can be seen that a certain role reversal has taken place in the last section where it is Launfal who occupies the feminine position of waiting for his rescuer to come, unable to act on his own behalf. Since it is Tryamour who takes the initiative, Launfal's sexual identity is somewhat feminised. The women have a degree of power, which contradicts the usual chivalric position of masculine activity and female passivity. The actively sexual mortal woman cannot be left unpunished. The desiring female who gazes upon men has her power of sight removed as Tryamour fulfils Guenevere's oath. She breathes on her eyes "That never eft myght sche se" (l. 1008) [So that she might never see again]. The putting out of eyes is a symbol of castration, eliminating the sexual power of the queen.

Unlike many romances Sir Launfal does not end, ultimately, in the restoration of the male subject to the public sphere. He rides away with Tryamour to her fairy kingdom. In contrast to Sir Degaré, the titular hero is not a positive force in purifying the social world. His story exposes the Arthurian court as a debased place where the execution of the king's justice is at the mercy of a woman's whims.

Unlike Launfal, Griselda does not violate her verbal contract. Despite the provocation, she is faithful to her initial promise never to be disobedient "in werk ne thoght" (1. 360) [neither in deed nor in thought]..$^{20}$ She freely submits her inner life as well as her external demeanour to Walter, putting her will at the service of his. Griselda is a woman subject to the whims of a man hierarchically superior to her on three counts: firstly on the grounds of gender-he is a man; secondly because of the traditional ranking of husbands and wives in marriage; ${ }^{21}$ and thirdly on class grounds since he is a marquis with a people to rule while she is just a poor peasant girl. As do a number of the stereotypes considered here she seems to derive from classical times ${ }^{22}$ and appears in the Aarne-Thompson index of folk tale motifs. ${ }^{23}$ Top Girls gives us a paradoxically traditional reading of Griselda as passively suffering the afflictions visited on her by the pater familias in his role as unappeasable tyrant. Though Churchill uses her as convenient shorthand for a certain type of female behaviour, the Middle Ages provided other potential readings. Her first known literary incarnation is, as Marlene reminds us, in the pages of Boccaccio's Decameron where Walter is indeed presented as "bonkers". Boccaccio uses the gender politics of marriage to scrutinise power politics in general, calling as much attention to the husband's despotism as to Griselda's patience. Petrarch translated Boccaccio into Latin, stressing the exemplary qualities of the story by turning it into an allegory of the soul's constancy in adversity, thus stripping away the importance of gender. Despite these non-realistic beginnings, the story was considered a relevant part of female identity formation in the Middle Ages. Griselda found her place in medieval conduct manuals as an ideal of wifely obedience, ${ }^{24}$ her utility as a paradigm persisting into the seventeenth century as recommended reading for the daughters of the bourgeoisie and of merchants (Golenistcheff-Koutouzoff 150). Nonetheless, it was also possible to see her as a figure of power: Christine de Pizan included Griselda's story in her Livre de la Cité des Dames (1405) as a riposte to men who characterise women as the weaker sex, speaking of her force of character and portraying her as a model of courage and of constancy (de Pizan 195, 201). These examples show that Griselda can be considered either as an avatar of the damsel in distress, the idealised sexual partner of Shippey's formulation, or as a strong woman. In his Clerk's Tale Chaucer took Petrarch's version, combining it with Le livre Griseldis, an 
anonymous French translation of Petrarch, in a rewriting that has troubled modern literary critics. Good and bad are far from clear in this tale, which, on one level, has been felt, as C. David Benson points out, to insult "human feelings and natural justice" ("Poetic Variety" 142).

The strong reaction which Chaucer's version elicits is partially attributable to his intensification of the pathos of Griselda's situation and to his criticism of Walter's behaviour. This activates affective responses in the audience which erode the distance necessary for an allegorical reading. The medieval audience was prepared to accept that the ways of God look inscrutable to man, but Chaucer undermines Walter's figural significance. The narrator constantly intervenes to express outrage at his needless testing of Griselda. As Elizabeth Salter indicates, "the Tale cannot be preserved as a lesson if [...] we are instructed, even encouraged to feel human contempt for the means by which that lesson is conveyed" (61). The scene in which her daughter is taken away from Griselda demonstrates the contradictory elements at play. The central problem is Griselda's apparently untroubled abandonment of her child to what she believes to be certain death. On the one hand, her constancy to the promise of utter obedience to Walter's will is stressed as is her stony self control, demonstrated by her lack of reaction "in word, or chiere, or contenaunce" (1. 499) [in word or look or deed] as her original promise stipulated. On the other, her maternal desire to kiss her daughter before she hands her over, cuddling her and blessing her, intensifies the pathos. However, her acknowledgement, "'For this nyght shaltow dyen for my sake"'(1. 560) [for this night you will die for my sake]-in other words as a consequence of her unswerving obedience to a higher will-puts the problem into stark relief. Such details force us to scrutinise not only Walter but also Griselda herself for submitting to his cruelty. She appears to be sacrificing the needs of her child to those of her husband, a husband whose actions have already been called into question by the narrator.

At the same time, Chaucer reinforces the figural and Biblical references, providing a number of explicit Christian allusions to support the case for allegorising Griselda. His reminder that:

... hye God somtyme senden kan

His grace into a litel oxes stall. (1l. 206-207)

[Almighty God can sometimes send his grace into a little ox's stall].

makes an obvious allusion to the birth of Christ. Indeed, as Benson argues, it is not Walter who is to be seen as figuring God and Griselda as figuring the human soul, but the contrary:

Beyond obeying Walter, she loves him, even in the face of his wickedness and rejection, and thus she is a figure [...] of Christ himself, who also knew how to be obedient even unto death and to love those who persecuted him. It is Griselda, not Walter, as some would have it, whose actions remind us of [...] the God of forgiveness and unqualified love. ("Poetic Variety"143)

Published in 1990, Benson and Robertson's book came at the end of a decade in which modern critics discovered proto-feminism in Chaucer. Benson even goes as far as to argue that, "Christian feminism so dominates Chaucer's religious tales that men are viewed with approval only when they begin to act like women" ("Introduction" 6). Furthermore, Chaucer uses the figure of Job to praise women's capacity to outdo men when it comes to displaying qualities in their quintessential form:

Men speke of Job, and moost for his humblesse,

As clerkes, whan hem list, konne wel endite, 
Mainly of men, but as in soothfastnesse,

Though clerkes preise wommen but a lite,

Ther kan no man in humblesse hym acquite

As wommen kan ..... (11. 932-7)

[Men speak of Job and mostly for his humility, as scholars know how to write when it pleases them, mainly about men, but in truth, though scholars praise women only

a little, no man can behave with as much humility as women can]

41 Job is the quintessential figure of constancy in adversity and the narrator claims that Griselda surpasses him. Though he is traditionally known for his patience rather than his humility, his story resonates with that of Griselda in that both refuse to repine and both have restored to them what they have lost. Furthermore, humility is an important aspect of Christian heroism. On the other hand, it may be noted that by sacrificing her maternal role to her sense of her own integrity, Griselda is acting more like a man. Indeed, Charlotte Morse argues that such steely dedication to her promise and steadfast bearing of the consequences can be found in medieval narratives in which the protagonist is male (79).

In general, however, Chaucer's version of the Griselda story is unsatisfactory to a modern audience because it seems to lack a clear focus. He encourages an allegorical reading which is then deliberately disturbed by other elements. This has been attributed to the aesthetic of Gothic art which is said to favour a lavish attention to detail rather than a sense of overall structure and effect (Salter 68). Whatever the reason, it can be seen that Griselda's Christ-like and Job-like qualities give her a masculine authority and an actively complicit role in her testing which disturbs the gender politics of wifely submission to a husband's will. For Chaucer, Griselda seems to be far from a damsel in distress. Her femininity is strategically important to him where he wishes to evoke maternal tenderness; but her dauntless self-dedication which transcends questions of gender makes her a figure of power rather than one of vulnerability.

Questions of identity, in one form or another, lie at the centre of the tales that have been considered. As has been seen, they all have some basis in folk tale or fairy tale and therefore use the techniques of traditional narrative: the characters perform roles or functions rather than having an individual psychology. What stereotypes of women show is that women as desiring subjects are problematic. Damsels in distress are rescued by their knights (unless they are fairy knights) and presumably "are happy mothers made." Sir Degaré and Sir Launfal are about the self-fulfilment of a knight in love as well as in chivalry. It is women's will-to-power that is seen as reprehensible in these romances and in such cases these women are often doubled by more conventional female figures. The opinionated, self-regarding mother in Lay le Freine is contrasted with her silent, self-denying daughter. Le Freine must achieve her aims indirectly through the feminised qualities of self-abnegation. The female narrative ostensibly reinforces these messages of passive service; Griselda must uncomplainingly obey Walter finally to be integrated into her nuclear family. Yet detailed analysis of individual romances has shown that women as characters tend to resist or even, in the case of Chaucer's Griselda, subvert the stereotypes. Sir Degaré, where the initial disruption of the social order focuses on woman's defenselessness in the face of male violence, seems to be preoccupied with female figures of vulnerability. Yet the precise function of Degaré's future bride is uncertainly configured, giving hints of otherworldy menace before resolving itself reassuringly into the stereotype of the damsel in 
distress. Le Freine's generous gesture may be seen as ambiguous: the laying of the cloth on the bed is as much an act of claiming as of giving. Where women are strong, men are correspondingly weak. Though the Arthurian court in Sir Launfal is a man's world, both Launfal's problems and their solutions are initiated by female figures. These powerful women take on masculine qualities in their sexual self-assertiveness and, in the case of Tryamour, in her ability to solve her knight's problems. Launfal himself is placed in a stereotypically feminised position of stasis and enclosure. But it is Chaucer's story of Griselda that shows that, paradoxically, women may be most powerful when they are most vulnerable. Griselda's total dedication to Walter's will may also have elements of self-assertion; Griselda's excessive single-mindedness in submitting to his commands may be seen to have masculine overtones. Her patience is shown to be a part of fortitude, Middle English strengthe (Blamires 173). This determination permits her to survive the tests with which she is confronted.

\section{BIBLIOGRAPHY}

Archibald, Elizabeth. "The Flight from Incest: Two Late Classical Precursors of the Constance Theme," The Chaucer Review 20: 4 (Spring, 1986): 259-72.

Benson, C. David. “Introduction.” In Chaucer's Religious Tales. Eds. C. David Benson and Elizabeth Robertson. Cambridge: D. S Brewer, 1990. 1-10.

---. “Poetic Variety in the Man of Law's and the Clerk's Tales." In Chaucer's Religious Tales. Eds. C. David Benson and Elizabeth Robertson. Cambridge: D. S Brewer, 1990. 137-44.

Benson, Larry D. (ed.). The Riverside Chaucer. Oxford: Oxford University Press, 1987.

Bettelheim, Bruno. The Uses of Enchantment: The Meaning and Importance of Fairy Tales. 1976. Harmondsworth: Penguin, 1982.

Blamires, Alcuin. Chaucer, Ethics, and Gender. Oxford and New York: Oxford University Press, 2006. Byatt, A.S. The Djinn in the Nightingale's Eye: Five Fairy Stories. 1994. London: Vintage, 1995.

Cate, W.A. "The Problem of the Origin of the Griselda Story," Studies in Philology XXIX: (1932): 389-405.

Churchill, Caryl. Top Girls. 1982. London and New York: Bloomsbury, 2013.

de Pizan, Christine. Le Livre de la Cité des Dames. 1405. Paris: Stock. 1986.

Foreman, Amanda. "Margaret Thatcher: The Accidental Feminist." (04.09.13). 04.09.14.

<www.thedailybeast.com/articles/2013/04/09/margaret-thatcher-the-accidentalfeminist.html>

Frye, Northrop. Anatomy of Criticism. 1957. Harmondsworth: Penguin, 1990.

Golenistcheff-Koutouzoff, Elie. L'Histoire de Griseldis en France au XIVe et au XVe Siècle. Thèse présentée à la Faculté des Lettres pour l'obtention du titre de docteur de l'Université de Paris. Paris: E. Droz , 1933. 
Kisor, Yvette. "Moments of Silence, Acts of Speech: Uncovering the Incest Motif in the Man of Law's Tale." Chaucer Review 40: 2 (2005): 141-62.

Laskaya, Anne and Eve Salisbury (eds.) The Middle English Breton Lays. Kalamazoo: MI, Medieval Institute Publications for TEAMS, "Middle English Texts," 1995.

Lévi-Strauss, Claude. Les Structures Elémentaires de la Parenté. 1947. Berlin and New York: Mouton de Gruyter, 2002.

Morse, Charlotte C. “Critical Approaches to the Clerk's Tale." In Chaucer's Religious Tales. Eds. C. David Benson and Elizabeth Robertson. Cambridge: D. S Brewer, 1990. 71-83.

Propp, V. Morphology of the Folktale. 1968. Austin: University of Texas Press, 1994.

Riddy, Felicity. "Middle English romance: family, marriage, intimacy." In The Cambridge Companion to Medieval Romance. Ed. Roberta L. Krueger. Cambridge: Cambridge University Press, 2000. 235-252.

Salter, Elizabeth. Chaucer: The Knight's Tale and The Clerk's Tale. 1962. London: Edward Arnold, 1969. Schlauch, Margaret. Chaucer's Constance and Accused Queens. 1927. New York: Gordian Press, 1969.

Shippey, T. A. "Breton Lais and Modern Fantasies." In Studies in Medieval English Romances. Ed. Derek Brewer. Cambridge: D.S. Brewer, 1991. 69-91.

Simpson, James. "Violence, Narrative and Proper Name: Sir Degaré, 'The Tale of Sir Gareth of Orkney,' and the Folie Tristan d'Oxford." In The Spirit of English Popular Romance. Eds. Ad Putter and Jane Gilbert. Harlow: Pearson Education, 2000. 122-141.

Spearing, A.C. The Medieval Poet as Voyeur: Looking and Listening in Medieval Love Narratives. Cambridge: Cambridge University Press, 1993.

Thompson, Stith. Motif-Index of Folk-Literature. A Classification of Narrative Elements in Folktales, Ballads, Myths, Fables, Medieval Romances, Exempla, Fabliaux, Jest-Books and Local Legends. 5 vols. Bloomington: Indiana University Press. 1955-58. The Aarne-Thompson index can be consulted online at <http://mirlyn.lib.umich.edu/Record/001276245> and <http://mirlyn.lib.umich.edu/ Record/004424656>

Vial, Claire. There and Back Again: The Middle English Breton Lays, a Journey through Uncertainties. Paris: Presses Universitaires de France, 2013.

Vincensini, Jean-Jacques. "De la merveille à la connaissance. Vocation anthropologique de la narration médiévale." In Adam et l'astragale. Essais d'anthropologie et d'histoire sur les limites de l'humaine. Sous la direction de Gil Bartholeyns, Pierre-Olivier Dittmar et al. Paris: Editions de la Maison des sciences de l'homme, 2009. 173-194.

\section{NOTES}

1. http://artchive.com/artchive/B/bruegel/mad_meg.jpg.html. Dull Gret or Mad Meg is the anglicised version of the name.

2. As Larry D. Benson points out, "The Griselda story is one of the most familiar and popular in European literature" (880).

3. Another fictional commentator on the Griselda story also gives a modern reaction. In A.S. Byatt's 1994 short story, "The Djinn in the Nightingale's Eye," Gillian Perholt, a narratologist, makes Griselda the subject of a talk she gives at a conference, "Stories of Women's Lives" in Ankara. She concludes, "And yet our own response is surely outrage-at what was done to 
Griselda-at what was taken from her, the best part of her life, what could not be restored [...]" (121). The interpretative focus here is not narrative shape, the reparative reunion with restored children and newly-devoted husband, which is the pattern folklorists often emphasise, but on the irrevocable loss of the years when Griselda believed her children to be dead.

4. The way powerful women culturally become perceived as too masculine is demonstrated by Amanda Foreman's obituary in which she recalls the "infamous Downing Street lunch" where one guest "joked, 'Is there any truth in the rumour that Mrs. Thatcher is a woman?' He was shushed but not before the entire table burst out laughing in agreement."

5. See the Middle Ages entry in https://en.wikipedia.org/wiki/Damsel_in_distress which cites Griselda as a major example of the type.

6. See Perseus and Andromeda among other classical stories. The hero saves the princess from the monster to which she is about to be sacrificed, thus giving rise to the "princess and dragon" motif which Northfrop Frye considers to be "the central theme of quest-romance" (189).

7. T. A. Shippey suggests that all the characters in traditional narratives "are (apart from the idealised sexual partner) father-figures, mother-figures or 'splits' or 'repeats' of the protagonist" (69-70).

8. Bruno Bettelheim notes that "Fairy tales deal in literary form with the basic problems of life, particularly those inherent in the struggle to achieve maturity" (183).

9. See Laskaya, Anne and Eve Salisbury (eds.). The Middle English Breton Lays. The lays are: Sir Orfeo, Lay le Freine, Sir Degaré, Emaré, Sir Launfal, Sir Gowther, Erle of Toulous, Sir Cleges. All quotations from these poems are taken from this edition.

10. Felicity Riddy argues that despite the "fantasies of freedom" that romance offers the man, there is a subliminal message to men and women of the propertied classes that they should settle down and ensure the continuity of the lineage (240).

11. Her behaving like Potiphar's wife as well as her preoccupation with the preeminence of her own beauty like the wicked queen from fairy tale will be discussed below.

12. My thanks to one of the readers of this article who drew my attention to Vincensini's study.

13. For incest taboos in general see Lévi-Strauss, Claude. Les Structures Elémentaires de la Parenté.

14. Space forbids a detailed discussion of the Constance or accused queen stereotype. In Emaré, another of the Middle English Breton Lays in the Salisbury and Laskaya edition, Emare is forced to flee her father's kingdom to escape his incestuous designs to marry her.

15. The Aarne-Thompson index of folk tale motifs is a list which allows folklorists to identify recurrent motifs in narratives.

16. Margaret Schlauch considers that the manifold legends of inaccessible princesses, who can only be won after their suitors have performed deeds of "impossible difficulty" to win them, derive from conditions in matrilineal societies in which inheritance went through the female line, prompting the father to take measures to resist being supplanted by the daughter's husband. (58).

17. Anne Laskaya notes, "The idea that twins were a sign of adultery was a popular belief in the Middle Ages, though it was condemned as ignorant by others" (Laskaya and Salisbury 81).

18. As Chaucer's Wife of Bath cheerfully admits: "For half so boldely kan ther no man/Swere and lyen, as a womman kan" (Larry D. Benson 108). [No man can swear and lie half as boldly as a woman can].

19. One might argue that a 15-foot giant is a particularly ferocious opponent, but Degaré's first combat was against a dragon and there he was armed only with an oak staff.

20. Quotations from The Clerk's Tale are taken from The Riverside Chaucer.

21. See Ephesians 5:22-23, "Wives, submit yourselves to your own husbands as you do to the Lord. For the husband is the head of the wife as Christ is the head of the church."

22. W.A. Cate considers that the story is a rationalised version of the Cupid and Psyche type of a mortal woman with a supernatural lover. This explains his capricious behaviour. 
23. As $\mathrm{N}^{\circ} 887$.

24. See, for example Le Ménagier de Paris in which the story of Griselda is included, The Book of the Knight of La Tour-Landry, or How the Goodwife Taught her Daughter.

\section{ABSTRACTS}

This article begins by discussing the way that medieval romance has been a means of transmission into modern times of stereotypes familiar from folk tale and fairy tale. Caryl Churchill's 1982 play Top Girls includes Patient Griselda among its cast of female characters, thus demonstrating that stereotypes are still a useful shorthand for certain types of female behaviour. However, such stereotypes are not limited to passive, suffering victims. Powerful figures like wicked queens and evil mothers are potential dark doubles to the damsel in distress and persecuted wife. I argue that these foundational stereotypes often appear as a feature of tales of identity in which the male subject position of active self-affirmation is partly developed in relation to female figures and is to be contrasted with the female narrative of passivity and vulnerability. Nonetheless, romances also question as much as they confirm these gender roles. The basic stereotypes may be disrupted or even subverted. Victimisation itself may be interrogated so that, with Chaucer's tale of Griselda, the paradox of subjection as a vector of selfassertion becomes apparent in the treatment of the material.

Cet article débute avec une étude de la façon dont le roman médiéval constitue un moyen de transmission vers l'époque contemporaine des stéréotypes devenus familiers dans les contes populaires et les contes de fée. La figure de Patient Griselda parmi les personnages Top Girls de Caryl Churchill, (1982) démontre que ces stéréotypes offrent encore aujourd'hui un raccourci pratique pour mettre en scène certains types de comportement féminin. Cependant, de tels stéréotypes ne se limitent pas à des victimes passives et endurantes. Des figures puissantes, reines malfaisantes ou mères malveillantes, constituent le versant ténébreux de la damoiselle en détresse ou de l'épouse persécutée. Le présent article postule que ces stéréotypes fondateurs apparaissent souvent dans les récits identitaires où la position du sujet masculin, en tant qu'agent actif dans l'affirmation de son être se construit pour partie en vis-à-vis des figures féminines, en nette opposition à un récit du féminin fondé sur la passivité et la vulnérabilité. Toutefois, les romans médiévaux remettent en question ces stéréotypes de genre autant qu'elles ne les confirment. Les stéréotypes simples sont parfois détournés, voire renversés. La notion même de victimisation est ainsi problématisée par Chaucer dans son conte de Griselda où le traitement du sujet met en évidence le paradoxe de la sujétion devenue vecteur de l'affirmation de soi.

\section{INDEX}

Keywords: Breton Lay, damsel in distress, fairy tale, folktale, gender, identity, medieval romance, self-assertion, stereotype, subjection, traditional narrative, vulnerability

Mots-clés: affirmation de soi, conte de fée, conte populaire, damoiselle en détresse, genre, identité, Lai Breton, roman médiéval, stéréotype, sujétion, vulnérabilité, récits traditionnels 


\section{AUTHORS}

\section{LESLEY LAWTON}

Maître de conférences

Université Toulouse - Jean Jaurès

lawton@univ-tlse2.fr 